\title{
QUALITY OF CARP MEAT (Cyprinus carpio) PRODUCED IN A POND WITH THE ADDITION OF PURIFIED WASTEWATER ORIGINATING FROM THE SLAUGHTERHOUSE
}

\author{
Miloš Pelićc ${ }^{*}$, Milica Živkov Baloš ${ }^{1}$, Nenad Popov ${ }^{1}$, \\ Suzana Vidaković Knežević ${ }^{1}$, Nikolina Novakov², \\ Nikola Puvača ${ }^{3}$, Dragana Ljubojević Pelić ${ }^{1}$
}

\author{
${ }^{1}$ Scientific Veterinary Institute „Novi Sad“, Novi Sad, Republic of Serbia \\ ${ }^{2}$ Faculty of Agriculture, University of Novi Sad, Novi Sad, Republic of Serbia \\ ${ }^{3}$ Faculty of Economics and Engineering Management, Department \\ of Engineering Management in Biotechnology, University \\ Business Academy, Novi Sad, Republic of Serbia
}

\section{Abstract}

The aim of the study was to investigate production parameters and nutritive quality of carp meat produced in a fish pond fed with fresh well water mixed with purified slaughterhouse wastewater. The quality of carp meat was analysed in view of seasonal variations in chemical composition of fillets. Our research idea was that purified slaughterhouse wastewater would provide essential nutrients for carp and positively affect the quality of fish meat, which was confirmed in this experiment. The total carp production at the end of study period was $3,270 \mathrm{~kg} / \mathrm{ha}$. The research revealed a feed conversion ratio (FCR) of $1.5 \mathrm{~kg}$ of feed per one $\mathrm{kg}$ weight gain and a survival rate of $87 \%$. Statistically significant difference $(p<0.05)$ between meat protein content during spring and autumn season was established. Protein content in meat was higher during spring season, whereas higher fat content was established during autumn sampling season. The application of purified slaughterhouse wastewater provided high level of nutrients resulting in high meat yield per area unit and good chemical composition of meat. Such production model is meaningful in both economic and ecological aspect.

Key words: carp, slaughterhouse, wastewater, meat quality, spring, autumn

${ }^{1 *}$ Corresponding Author: milosp@niv.ns.ac.rs 


\title{
KVALITET MESA ŠARANA (Cyprinus carpio) PROIZVEDENOG U RIBNJAKU SA DODATKOM PREČIŠĆENE OTPADNE VODE POREKLOM IZ KLANICE
}

\author{
Miloš Pelić ${ }^{1}$, Milica Živkov Baloš ${ }^{1}$, Nenad Popov ${ }^{1}$, \\ Suzana Vidaković Knežević ${ }^{1}$, Nikolina Novakov², \\ Nikola Puvača ${ }^{3}$, Dragana Ljubojević Pelić ${ }^{1}$
}

\footnotetext{
${ }^{1}$ Naučni institut za veterinarstvo „Novi Sad“, Novi Sad, Republika Srbija

${ }^{2}$ Poljoprivredni fakultet, Univerzitet u Novom Sadu, Republika Srbija

${ }^{3}$ Fakultet za ekonomiju i inženjerski menadžment, Departman za

inženjerski menadžment u agrobiznisu, Novi Sad, Republika Srbija
}

\section{Kratak sadržaj}

Cilj ovog rada je ispitivanje proizvodnih parametara i nutritivnog kvaliteta mesa šarana proizvedenog u ribnjaku koji je punjen bunarskom vodom sa dodatkom prečišćene vode iz klanice. Ispitani su hemijski parametri kvaliteta fileta šarana kao i uticaj godišnjeg doba kada je izvršeno uzorkovanje. U ovom istraživanju ideja je bila da će prečišćena otpadna voda iz klanice obezbediti hranjive materije za šarana i da će pozitivno uticati na kvalitet mesa, što je ogledom i potvrđeno. Utvrđeno je da je ukupna proizvodnja šarana na kraju ogleda bila 3,270 kg/ha. Konverzija je bila oko $1.5 \mathrm{~kg}$ hrane za kg prirasta, a stopa preživljavanja 87\%. Sadržaj proteina u mesu je bio viši u proleće u odnosu na jesen i razlika je bila statistički značajna ( $\mathrm{p}<0.05)$. Sadržaj masti u mesu je bio viši u jesenjem uzorkovanju. Korišćenjem prečišćene otpadne vode iz klanice za uzgoj šarana, je obezbeđen visok nivo hranjivih materija što je rezultiralo visokim prinosom mesa po jedinici površine i dobrim hemijskim sastavom mesa. Ovakav vid proizvodnje je značajan sa ekonomskog i ekološkog aspekta.

Ključne reči: šaran, klanica, otpadna voda, kvalitet mesa, proleće, jesen

\section{INTRODUCTION}

In some regions, wastewater from slaughterhouses is still released into the rivers, channels, lakes and other water bodies without adequate pre-treatment. This causes substantial hazard for the environment. Such wastewaters contain high quantity of organic matter that represents an excellent source of nutrients 
for carp species. Vo (2001), Thi Phong Lan et al. (2007) and Pelić (2020) reported that such wastewaters can be used in aquaculture as a source of both water and important nutrients for fish. The use of purified wastewater in fishponds is an innovative recycling method implicating conversion of soluble nutrients into biomass, that is, fish. It can be considered a completely novel approach to providing sustainability of meat industry and environment protection (Pelić, 2020). Carp is an omnivorous fish species that feeds on natural food available in the pond, which makes it particularly suitable for farming in such systems. Fish meat is a valuable source of nutrients, which is essential for variable and healthy human diet. An optimal ratio of proteins, fats, carbohydrates, minerals and vitamins contributes to a high nutritive value of fish meat (Ćirković et al., 2011). It contains up to $85 \%$ water, 16 to $22 \%$ proteins, 1 to $20 \%$ fat and 0.8 to $2 \% \mathrm{~min}$ erals (Ljubojević et al., 2013a; 2013b). The amounts of nutrients in fish meat are highly variable depending on a wide range of factors such as genetic, species, age, diet, gender, health condition, season of the year, water quality, farming system, etc. (Marković et al., 2016; Ljubojević Pelić et al., 2018). Proteins from fish are characterized by good amino-acid composition with substantial amounts of free amino acids (Buchtová et al., 2010). Fish proteins contain all aminoacids essential for human body and can be used as the sole source of protein in the diet (Vladau et al., 2008). Fish meat contains much less connective tissue comparative to the meat of endothermic animals, which contributes to its better digestibility preferred by specific consumer categories (Vladau et al., 2008). Fish contains negligible amounts of carbohydrates in the form of glycogen and high water content (60-86\%) (Ćirković et al., 2011). Fish meat fat content is highly variable. Accordingly, based on their fat content, fishes are categorized into lean ( $<5 \%$ fat), semi-fat ( 5 - 10\% fat) and fat ( $>10 \%$ fat) (Ljubojević et al., 2013b). Being a most valuable source of polyunsaturated fatty acids, especially eicosapentaenoic acid (EPA) and docosahexaenoic acid (DHA) that can only be effectively synthesized by aquatic organisms, consumption of fish meat is the only way to intake the aforementioned fatty acids by humans (Pal et al., 2018). Thus, regular use of fish in the diet is highly recommended.

Fish consumption is beneficial and associated with lower risk of dementia and Alzheimer disease, and protective effects against some cancers are suggested (Connor and Connor, 2010). Regular intake of fish decreases the risk from cardiovascular diseases, especially myocardial infarction, atherosclerosis, hypertension and other (Kris-Etherton et al., 2002). Positive effects of fish in human diet are established in view of prenatal development, preservation of functions of nervous system, eyes and skin (Allen and Harris, 2001). Specific flavor, taste and good digestibility contribute to overall acceptability of carp meat. 
Considering the aforementioned, investigating the options of fish farming by using purified wastewater is highly supported. The lack of available literature data on production parameters and meat quality of fish reared in ponds filled with purified wastewater encouraged our research towards determining production parameters and meat quality of carps farmed under the described conditions. To that end, carp fillets were analysed for basic quality parameters. Moreover, the carp fillet samples were examined during two sampling periods in order to identify potential seasonal effects on meat quality.

\section{MATERIAL AND METHODS}

A 1 ha fish pond with average depth of $1.3 \mathrm{~m}$ was set up as a part of the meat industry „Đurđević” in Pećinci providing an integrated production structure including slaughterhouse, wastewater purification system and fish pond. The process of water purification was performed in a wastewater treatment system. The purification procedure includes physical, biological and chemical processes. First, untreated wastewater was mechanically treated. Afterwards, water flows into the aeration tank and undergoes biological processing. Finally, the wastewater is discharged into the secondary wastewater treatment tank and chemically treated. The pond was built at the high-quality arable land and in line with basic principles and requirements described by Ćirković et al. (2002). The pond is supplied with both well water and purified slaughterhouse wastewater under continuous aeration. The ratio of water from the well and purified water from the slaughterhouse was about 2:1. In the first year, two-year old carps purchased from commercial ponds were introduced with a stocking density of 2,500 individuals/ha. The average initial weight of carps was $200 \mathrm{~g}$. Fish were fed mixture of grains and edible offal (spleen, liver) of slaughtered animals supplemented with complete carp-feed mixtures. Edible offal was heat-treated (cooking) at a temperature of $90{ }^{\circ} \mathrm{C}$. The offal has been finely ground and mixed in a cutter with the addition of cereals until obtaining a doughy consistency. The relationship between fresh feed (grains and edible offal) and complete mixtures in spring was 1:1. The ratio in fresh feed used was $30 \%$ for grains and $70 \%$ for edible offal. At the end of the first year, the survival rate was $74 \%$. Production parameters were calculated according to fish biomass and feed conversion ratio described Abdelghany and Ahmad (2002). The first sampling was carried out in April next year, and the second one in the same year in October, that is, at the end of experimental period. In the second year, the survival rate was $87 \%$. During the last three months, only grains and complete mixtures were added in the ratio 1:1. The samples of three-year-old 
common carp were transported to the laboratory in a transport cooler. All samples were filleted before analysis.

Chemical composition of fish was examined applying standard SRPS ISO methods. Gravimetric method was utilized to determine the moisture content (SRPS ISO 1442:1998) and total fat (SRPS ISO 1443:1992); total protein content was determined combustion method (AOAC Official Method 992.15). Ash content was determined by combustion at $550 \pm 25^{\circ} \mathrm{C}$ applying standard method SRPS ISO 936:1999. Salt concentration was determined applying standard method SRPS ISO 1841-1:1999. Hydroxyproline level was measured spectrophotometrically applying SRPS ISO 3496:2002. Subsequently, collagen content and collagen content in total protein were calculated. Energy value was expressed per $100 \mathrm{~g}$ of carp fillet, and was calculated according to the equation below using conversion factors indicated in the Appendix 13 of the Rulebook on declaration, labelling and advertising of food ("Official Gazette of RS", No. 19/2017, 16/2018, 17/2020 and 118/2020): Energy value (kcal/g) $=4 \times$ carbohydrate content $+4 \times$ protein content $+9 \times$ fat content.

\section{Statistical data analysis}

The data were analysed using Excel (Microsoft Excel 2007, Microsoft Corporation, Redmond WA, USA) software package and Data Analysis. Student's $\mathrm{t}$-test was applied to compare the arithmetic mean values of the results obtained for samples collected in spring and autumn. The data were expressed as mean values $\pm S D$. A $p$-value of $p<0.05$ was considered a statistically significant difference. Besides, Pearson correlation coefficient was used as well.

\section{RESULTS}

Production parameters were determined during harvesting at the end of study period. Total carp production per area unit was $3,270 \mathrm{~kg} / \mathrm{ha}$. Feed conversion calculated as the amount of supplementary feed spent for $1 \mathrm{~kg}$ weight gain was around $1.5 \mathrm{~kg}$. Survival rate was high, reaching $87 \%$. At spring sampling, in April in the second year of the study, the carp body weight ranged from 695 to $1,675 \mathrm{~g}$ (average weight $820 \mathrm{~g}$ ), whereas values at autumn sampling in October in the second year of the study ranged between 1,710 and 2,700 g. At the end of experimental period in October in the second year of the study, the average live body weight of three-year old common carp was 2,020 $\pm 252.3 \mathrm{~g}$.

Chemical composition of carp fillet is shown in Table 1. Higher protein content $(17.99 \mathrm{~g} / 100 \mathrm{~g})$ in fillets was determined in spring period. The differ- 
ence between spring and autumn protein content was statistically significant $(\mathrm{p}<0.05)$. The obtained results revealed higher fat content in the fillets during autumn period $(5.19 \mathrm{~g} / 100 \mathrm{~g})$ as compared with the spring season; however, the difference is not statistically significant $(\mathrm{p}>0.05)$. Salt content was significantly higher at spring sampling $(\mathrm{p}<0.05)$. The differences in energy value of the fillets analyzed in spring and autumn period were not statistically significant $(\mathrm{p}>0.05)$.

Table 1. Chemical composition of carp fillet produced in the integrated system, sampled during spring and autumn season

\begin{tabular}{llll}
\hline \multicolumn{1}{c}{ Parameters (\%) } & Spring & Autumn & p-value \\
\hline Moisture content & $74.95 \pm 1.37$ & $76.16 \pm 1.27$ & 0.03 \\
\hline Protein content & $17.99 \pm 0.40$ & $17.67 \pm 0.29$ & 0.03 \\
\hline Fat content & $4.57 \pm 1.35$ & $5.19 \pm 1.55$ & 0.29 \\
\hline Collagen & $1.04 \pm 0.43$ & $1.07 \pm 0.13$ & 0.84 \\
\hline Collagen content in total protein & $5.80 \pm 2.44$ & $6.05 \pm 0.78$ & 0.73 \\
\hline Salt & $1.26 \pm 0.25$ & $0.52 \pm 0.26$ & $<0.05$ \\
\hline Energy value (kcal) & $113.06 \pm 11.27$ & $117.38 \pm 13.09$ & 0.38 \\
\hline
\end{tabular}

The results were expressed as mean values $\pm \operatorname{SD}(n=7) ; \mathrm{p}<0.05$

\section{DISCUSSION}

To our knowledge and according to the available literature the data on production performance and meat quality of carps reared in purified wastewater are pretty sparse, which suggests the innovative character of our study. The obtained results on production parameters correspond with the production parameters of carps sampled in conventional fishponds in the Republic of Serbia. Total carp production per area unit recorded in this study was 3,270 $\mathrm{kg} / \mathrm{ha}$. In fishponds with semi-intensive production system, where fish is fed naturally available feed resources supplemented with grains, the production performance is up to $1,500 \mathrm{~kg} / \mathrm{ha}$ (Marković et al., 2016). Rearing fish in good production conditions and the use of high-quality concentrated extruded feed would offer possibility of increasing production performance and yields that may reach over 3,000 kg/ha (Stanković et al., 2011).

Adequate knowledge about fish meat quality is of importance in view of its role and value in human diet (Kris-Etherton et al., 2002, Connor and Connor, 
2010). Our research revealed that moisture content in carp meat samples collected in spring season $(74.95 \pm 1.37 \%)$ was significantly lower (statistical significance $\mathrm{p}=0.03$ ) as compared to values measured in autumn period (76.16 $\pm 1.27 \%)$. Protein content determined in spring period $(17.99 \pm 0.40 \%)$ was higher than that observed in autumn $(17.67 \pm 0.29 \%)$, which is considered statistically significant $(\mathrm{p}=0.03)$. Fat content in spring $(4.57 \pm 1.35 \%)$ was lower than that in autumn season $(5.19 \pm 1.55 \%)$; however, the difference was not statistically significant $(\mathrm{p}=0.29)$. Higher contents of fat in autumn period could be attributed to the increased body-size of the fish. Also, nutrition as well as the types of fish feed play a very important role in the fat content in the body of fish (Stanković et al., 2011; Trbović et al., 2013; Marković et al., 2016). Some earlier researches have proved high correlation between the body-size of the carp and fat content in the meat (Kocour et al., 2007). A negative correlation was observed between fat and moisture contents in carps. Pearson correlation coefficients for the aforementioned parameters were 0.97 and 0.96 in spring and autumn season, respectively, which indicates a high negative correlation. Collagen contents determined in spring and autumn were $1.04 \pm 0.43 \%$ and 1.07 $\pm 0.13 \%$, respectively, with no statistically significant differences $(\mathrm{p}=0.84)$. Collagen content in total protein was lower in spring season $(5.80 \pm 2.44)$ as compared to autumn period $(6.05 \pm 0.78 \%)$, yet without statistically significant difference $(p=0.73)$. Calculated energy value was higher in autumn (117.38 \pm $13.09 \mathrm{kcal})$ than in spring $(113.06 \pm 11.27 \mathrm{kcal})$ without statistically significant difference $(p=0.38)$. The difference in calculated energy values in spring and autumn periods is expected, having in mind higher fat content in carp fillets sampled in October as compared to those sampled in April. According to the results reported by Yeganeh et al. (2012), fat and protein contents in samples of both "wild" carp and farmed carp decreased from summer to spring, whereas moisture contents increased during the same period. Over a 6-month research conducted between May and October, Swapna et al. (2010) did not establish any significant seasonal variations in fat contents in fish meat. On the other hand, Guler et al. (2008) reported highest fat content in carp fillets during winter months. This difference was explained by well-known seasonal variation in fat content associated with the changes of environmental temperature. According to the results obtained by Rasoarahona et al. (2004), fat content in carp muscle tissue was lower during warm months and higher during colder period of the year. It is to be emphasized that chemical parameters in wild fish are highly determined by the conditions of aquatic environment, which is well established source of nutritive matter. In farmed fish, diet containing commercially available feed-mixtures provides the abundance of nutrients thus determining the composition of meat. Protein content in meat is mainly determined 
by intrinsic factors such as species and size of the fish rather than by the diet itself. Fat content in the meat of farmed carp reported by Yeganeh et al. (2012) was in accordance with the results obtained in our study. With respect to protein contents determined in spring and autumn periods, Yeganeh et al. (2012) did not report any statistically significant seasonal differences. The obtained results suggest a favorable ratio of nutritive matters in farmed carp, which could be attributed to high level of available nutrients in purified slaughterhouse wastewater. The results obtained in our study are in compliance with the results reported by other authors, who have conducted a number of researches on carp meat quality in diverse production systems. Chemical composition of carp meat was closely similar to fish reared in semi-intensive farming system in a commercial fishpond, where carps were fed concentrated feed mixtures and their meat had protein content of $17.30 \pm 0.39 \%$ and fat content of $3.41 \pm 1.37 \%$ (Ljubojević et al., 2013c). Such protein content is significantly higher and fat content significantly lower as compared to the cage-farmed carps of the same body weight, which were fed with corn. The protein and fat contents established in these carps were $16.23 \pm 0.54 \%$ and $9.79 \%$, respectively (Ljubojević et al., 2013c). A range of earlier researches suggested substantial variability in the quality of carp meat depending on the age, farming system and diet of the fish (Marković et al., 2016). The reported fat contents in carp meat ranged between 2.3 and $16.8 \%$, while somewhat lower variability was observed with respect to protein contents, which was within a range from 14 to 18\% (Vladau et al., 2008; Trbović et al., 2009; Ćirković et al., 2011).

Protein content in fillets of carp from semi-intensive production system fed diet supplemented with corn and wheat reported by Ćirković et al. (2011) was $15.59 \%$, whereas our results obtained in samples collected in spring and autumn season were $17.99 \%$ and $17.67 \%$, respectively. Interestingly, significantly lower protein content was measured in fillets sampled during autumn season (17.67\%) as compared with the results obtained in spring sampling period $(17.99 \%)$. This could be attributed to the effects of diet, that is, higher percentage of grains in fish diet in autumn period, having in mind that no edible offal were added in the last three months. Ljubojević et al. (2015) observed that decreased protein content in fish feed results in an increase in fat content and decrease in moisture and protein contents in fish muscle tissue. Increased amount of carbohydrates in carp diet leads to a more extensive deposition of visceral and muscle fat (Trbović et al., 2013). The fat content in fish meat varies according to the species, season of the year, water temperature and diet (Guler et al., 2008, Ćirković et al., 2011). Elevated fat content in carp meat negatively affects its sensory characteristics because increased fat amount affects the meat consistency and texture. 


\section{CONCLUSION}

The use of purified slaughterhouse wastewater in carp fish-pond positively affected the production parameters and resulted in production of carp characterized by adequate meat quality corresponding with that of the carp reared in conventional production systems.

The results of this research and their comparison with earlier researches on the quality of carp meat strongly suggest that the use of purified slaughterhouse wastewater results in a production of good-quality carp meat.

The use of slaughterhouse wastewater in fish production represents a novel approach to the sustainability of meat industry and environment protection. The application of this concept within a slaughterhouse is crucial in the aspect of environment protection, having in mind the requirements and standards aimed at minimizing the environment pollution imposed by EU. In that respect, such requirements have to be fulfilled, and Serbian legislation on environment protection must be harmonized with the EU regulations.

\section{ACKNOWLEDGEMENT}

This work was funded by Ministry of Education, Science and Technological development of Republic of Serbia by the Contract of implementation and financing of scientific research work of NIV-NS in 2021, Contract No: 451-039/2021-14/200031 from 05/02/2021.

\section{Author's Contribution:}

MP and DLJP made substantial contributions to basic idea, conception and design, acquisition of samples and data, analysis of the data and interpretation of results; NP, NN, NP and SVK was involved in drafting of the manuscript, revising it critically for important intellectual content, and DLJP and MŽB gave the final approval of the manuscript to be published.

\section{Competing interest}

The authors declare that they have no competing interests. 


\section{REFERENCES}

1. Allen K. G. D., Harris M. A. 2001. The Role of n-3 Fatty Acids in Gestation and Parturition. Experimental Biology and Medicine, 226, 498-506. doi:10.1177/153537020122600602.

2. Abdelghany A. E., Ahmad, M. H. 2002. Effects of feeding rates on growth and production of Nile tilapia, common carp and silver carp polycultured in fertilized ponds. Aquaculture Research, 33, 415-423. doi: 10.1046/j.13652109.2002.00689.x.

3. Buchtová H., Svobodová Z., Kocour M., Velíšek J. 2010. Chemical Composition of Fillets of Mirror Crossbreds Common Carp (Cyprinus carpio L.). Acta Veterinaria Brno, 79, 551-557. doi:10.2754/avb201079040551.

4. Connor W.E., Connor S.L. (2010) N-3 Fatty Acids from Fish and Plants: Primary and Secondary Prevention of Cardiovascular Disease. In: Bendich A., Deckelbaum R. (eds) Preventive Nutrition. Nutrition and Health. Humana Press. https://doi.org/10.1007/978-1-60327-542-2_10.

5. Ćirković M., Jovanović B., Maletin S. 2002. Ribarstvo, Univerzitet u Novom Sadu, Poljoprivredni fakultet, ISBN - 86-7520-013-7.

6. Ćirković M., Trbović D., Ljubojević D., Đorđević V. 2011. Meat quality of fish farmed in polyculture in carp ponds in Republic of Serbia. Tehnologija mesa, 52, 106-121.

7. Guler G. O., Kiztanir B., Aktumsek A., Citil O. B., Ozparlak H. 2008. Determination of the seasonal changes on total fatty acid composition and $\omega 3 / \omega 6$ ratios of carp (Cyprinus carpio L.) muscle lipids in Beysehir Lake (Turkey). Food Chemistry, 108, 2, 689-694. doi:10.1016/j.foodchem.2007.10.080.

8. Kocour M., Mauger S., Rodina M., Gela D., Linhart O., Vandeputte M. 2007. Heritability estimates for processing and quality traits in common carp (Cyprinus carpio L.) using a molecular pedigree. Aquaculture, 270, 43-50. doi:10.1016/j.aquaculture.2007.03.001.

9. Kris-Etherton P. M., Harris W. S., Appel L. J. Nutrition committee. AHA scientific statement. 2002. Fish consumption, fish oil, omega-3 fatty acids, and cardiovascular disease. Circulation, 106, 2747-2757. doi:10.1161/01. CIR.0000038493.65177.94.

10. Ljubojević D., Ćirković M., Novakov N., Jovanović R., Janković S., Đorđević V., Mašić Z. 2013a. Productivity and Meat Nutrient in Fish: The Diet Effect. Kafkas Universitesi Veteriner Fakultesi Dergisi, 19, 43-49. doi:10.9775/kvfd.2012.7088.

11. Ljubojević D.; Ćirković M.; Đorđević V.; Puvaĉa N., Trbović D.; Vukadinov J., Plavša N. 2013b. Fat quality of marketable fresh water fish speci- 
es in the Republic of Serbia. Czech Journal of food sciences, 31, 445-450. doi:10.17221/53/2013-CJFS.

12. Ljubojević D., Ćirković M., Đorđević V., Trbović D., Vranić D., Novakov N., Mašić Z. 2013c. Chemical composition, cholesterol content and fatty acid profiles of common carp (Cyprinus carpio) from free-catch, semi-intensive and cage system. Tehnologija mesa, 54(1), 48-56.

13. Ljubojević D., Radosavljević V., Puvača N., Živkov Baloš M., Đorđević V., Jovanović R., Ćirković M. 2015. Interactive effects of dietary protein level and oil source on proximate composition and fatty acid composition in common carp (Cyprinus carpio L.). Journal of Food Composition and Analysis, 37, 44- 50. doi:10.1016/j.jfca.2014.09.005.

14. Ljubojević Pelić D. 2018. Accession of carcass quality of common carp (Cyprinus carpio L.). Journal of Agronomy, Technology and Engineering Management, 1, 119-123.

15. Marković Z., Stanković M., Rašković B., Dulić Z., Živić I., Poleksić V. 2016. Comparative analysis of using cereal grains and compound feed in semiintensive common carp pond production. Aquaculture international, 24, 1699-1723. doi:10.1007/s10499-016-0076-Z.

16. Pal J., Shukla B. N., Maurya A. K., Verma H. O., Pandey G., Amitha A. 2018. A review on role of fish in human nutrition with special emphasis to essential fatty acid. International Journal of Fisheries and Aquatic Studies, 6, 2, 427-430.

17. Pelić M.M. 2020. Examination of the Effect of Using Wastewater from Slaughterhouses on Health and Production of Carp Meat (Cyprinus carpio) Safe for Human Consumption. PhD Thesis, Univerzitet u Beogradu-Fakultet veterinarske medicine.

18. Rasoarahona J. R., Barnathan G., Bianchini J. P., Gaydou E. M. 2004. Annual evolution of fatty acid profile from muscle lipids of the common carp (Cyprinus carpio) in Madagascar inland waters. Journal of agricultural and food chemistry, 52(24), 7339-7344. doi:10.1021/jf048993y.

19. Rulebook on declaration, labeling and advertising of food. Official Gazette of RS, No. 19/2017, 16/2018, 17/2020 and 118/2020.

20. SRPS ISO 1442/1998. - Meat and meat products - Determination of moisture content.

21. SRPS ISO 1443/1992. - Meat and meat products - Determination of total fat content.

22. SRPS ISO 1841-1:1999 - Meat and meat products - Determination of chloride content - Part 1: Volhard method.

23. SRPS ISO 3496:2002 - Meat and meat products - Determination of hydroxyproline content. 
24. SRPS ISO 936:1999. - Meat and meat products - Determination of total ash.

25. Stanković M. B., Dulić Z. P., Marković Z. Z. 2011. Protein sources and their significance in carp (Cyprinus carpio L.) nutrition. Journal of Agricultural Sciences, 56, 75-86. doi: 10.2298/JAS1101075S.

26. Swapna H. C., Rai A. K., Bhaskar N., Sachindra, N. M. 2010. Lipid classes and fatty acid profile of selected Indian fresh water fishes. Journal of Food Science and Technology, 47, 4, 394-400. doi:10.1007/s13197-010-0065-6.

27. Thi Phong Lan N., Dalsgaard A., Cam P. D., Mara D. 2007. Microbiological quality of fish grown in wastewater-fed and non-wastewater-fed fishponds in Hanoi, Vietnam: influence of hygiene practices in local retail markets. Journal of Water and Health, 5, 2, 209-218. doi:10.2166/wh.2007.014b.

28. Trbović D, Vranić D, Đinović J, Borović B, Spirić D, Babić J, Spirić A. 2009. Fatty acid profile and cholesterol content in muscle tissue of one year old common carp (Cyprinus carpio) during growth. Tehnologija mesa, 50. 5/6, 276-286.

29. Trbović D., Marković Z., Milojković-Opsenica D., Petronijević R., Spirić D., Djinović-Stojanović J., Spirić A. 2013. Influence of diet on proximate composition and fatty acid profile in common carp (Cyprinus carpio). Journal of food composition and analysis, 31, 1, 75-81. doi:10.1016/j. jfca.2013.04.002.

30. Vladau V. V., Bud I., Stefan R. 2008. Nutritive value of fish meat comparative to some animals meat. Bulletin of University of Agricultural Sciences and Veterinary Medicine. Animal Sciences and Biotechnologies, 65, 1/2, 301-305.

31. Vo Q. H. 2001. Wastewater reuse through aquaculture in Hanoi: status and prospects. In Working Paper No. 30, Wastewater Reuse in Agriculture in Vietnam: Water Management, Environment and Human Health Aspects, Proceedings of a Workshop held in Hanoi, Vietnam 14 March 2001, ed. L. RaschidSally, W. van der Hoe, M. Ranawaka, International Water Management Institute, Colombo, Sri Lanka, pp.20-23.

32. Yeganeh S., Shabanpour B., Hosseini H., Imanpour M., Shabani A. 2012. Comparison of farmed and wild common carp (Cyprinus carpio): Seasonal variations in chemical composition and fatty acid profile. Czech Journal of Food Sciences, 30, 6, 503-511. doi:10.17221/455/2011. 